University of Nebraska - Lincoln

DigitalCommons@University of Nebraska - Lincoln

Biological Systems Engineering: Papers and

Publications

Biological Systems Engineering

4-2012

\title{
Evaluation of the bank stability and toe erosion model (BSTEM) for predicting lateral retreat on composite streambanks
}

Taber L. Midgley

Oklahoma State University - Main Campus, taber.midgley@okstate.edu

Garey A. Fox

Oklahoma State University - Main Campus, gafox2@ncsu.edu

Derek M. Heeren

University of Nebraska-Lincoln, derek.heeren@unl.edu

Follow this and additional works at: https://digitalcommons.unl.edu/biosysengfacpub

Part of the Bioresource and Agricultural Engineering Commons, Environmental Engineering Commons, and the Other Civil and Environmental Engineering Commons

Midgley, Taber L.; Fox, Garey A.; and Heeren, Derek M., "Evaluation of the bank stability and toe erosion model (BSTEM) for predicting lateral retreat on composite streambanks" (2012). Biological Systems Engineering: Papers and Publications. 312.

https://digitalcommons.unl.edu/biosysengfacpub/312

This Article is brought to you for free and open access by the Biological Systems Engineering at DigitalCommons@University of Nebraska - Lincoln. It has been accepted for inclusion in Biological Systems Engineering: Papers and Publications by an authorized administrator of DigitalCommons@University of Nebraska Lincoln. 


\title{
Evaluation of the bank stability and toe erosion model (BSTEM) for predicting lateral retreat on composite streambanks
}

\author{
Taber L. Midgley, Garey A. Fox, and Derek M. Heeren \\ Department of Biosystems and Agricultural Engineering, Oklahoma State University, \\ 111 Ag Hall, Stillwater, Oklahoma 74078-6016, USA \\ Corresponding author - G. A. Fox, tel 405 744-8423, fax 405 744-6059, email garey.fox@okstate.edu
}

\begin{abstract}
Streambank erosion is known to be a major source of sediment in streams and rivers. The Bank Stability and Toe Erosion Model (BSTEM) was developed in order to predict streambank retreat due to both fluvial erosion and geotechnical failure. However, few, if any, model evaluations using long-term streambank retreat data have been performed. The objectives of this research were to (1) monitor long-term composite streambank retreat during a hydraulically active period on a rapidly migrating stream, (2) evaluate BSTEM's ability to predict the measured streambank retreat, and (3) assess the importance of accurate geotechnical, fluvial erosion, and near-bank pore-water pressure properties. The Barren Fork Creek in northeastern Oklahoma laterally eroded 7.8 to $20.9 \mathrm{~m}$ along a 100-m length of stream between April and October 2009 based on regular bank location surveys. The most significant lateral retreat occurred in mid- to late-May and September due to a series of storm events, and not necessarily the most extreme events observed during the monitoring period. BSTEM (version 5.2) was not originally programmed to run multiple hydrographs iteratively, so a subroutine was written that automatically input the temporal sequence of stream stage and to lag the water table in the near-bank ground water depending on user settings. Eight BSTEM simulations of the Barren Fork Creek streambank were performed using combinations of the following input data: with and without a water table lag; default BSTEM geotechnical parameters (moderate silt loam) versus laboratory measured geotechnical parameters based on direct shear tests on saturated soil samples; and default BSTEM fluvial erosion parameters versus field measured fluvial erosion parameters from submerged jet tests. Using default BSTEM input values underestimated the actual erosion that occurred. Lagging the water table predicted more geotechnical failures resulting in greater streambank retreat. Using measured fluvial and geotechnical parameters and a water table lag also under predicted retreat (approximately $3.3 \mathrm{~m}$ ), but did predict the appropriate timing of streambank collapses. The under prediction of retreat was hypothesized to be due to over predicting the critical shear stress of the non-cohesive gravel, under predicting the erodibility of the non-cohesive gravel, and/or under predicting the imposed shear stress acting on the streambank. Current research improving our understanding of shear stress distributions, streambank pore-water pressure dynamics, and methods for estimating excess shear stress parameters for noncohesive soils will be critical for improving BSTEM and other streambank stability models.
\end{abstract}

Keywords: BSTEM, Fluvial erosion, Mass wasting, Ozark ecoregion, Streambank erosion, Streambank stability

\section{Introduction}

Excessive sediment is one of the most common surface water pollutants. It diminishes water quality and destroys aquatic habitat. Streambank erosion is known to contribute a majority of the total sediment load to streams and rivers in some watersheds (Simon and Darby, 1999; Sekely et al., 2002; Evans et al., 2006; Wilson et al., 2008). In fact, sediment loads and streambank stability have been major concerns for decades and abundant money has been spent on stream bank stabilization (Lavendel, 2002; Bernhardt et al., 2005). This is an expensive practice but important for slowing bank retreat accelerated by land use change and reducing downstream sediment concentrations.
Several mechanisms can lead to streambank failure and sediment loading to streams including toe erosion by stream flow undercutting the bank and bank sloughing by removal of matric suction (i.e., generation of positive pore-water pressure) due to precipitation infiltration or streambank storage (Crosta and di Prisco, 1999; Simon and Collison, 2002). Streambank stability models are commonly utilized to investigate the primary mechanisms of bank instability and propose strategies for stabilizing streambanks. One of the most commonly used and most advanced streambank stability models is the Bank Stability and Toe Erosion Model (BSTEM), developed by the National Sedimentation Laboratory in Oxford, Mississippi, USA (Simon et al., 2000). BSTEM has been continually modified and improved by the authors since its creation. The most current public model is 
BSTEM version 5.2 and consists of two different components: a bank stability module and a toe erosion module.

To model bank stability, BSTEM calculates a factor of safety $(F o S)$ using three different limit equilibrium-method models: horizontal layers, vertical slices, and cantilever shear failure. Across horizontal layers, the model accounts for up to five user-input soil layers with unique geotechnical properties. Along vertical slices, the model examines the normal and shear forces active in slices of the failure blocks (portions of the bank above the failure surface). In general, FoS is calculated as the ratio between the resisting forces and the driving forces along a potential failure plane. The resisting forces can be defined by the Mohr-Coulomb equation:

$$
s_{\mathrm{r}}=c^{\prime}+\left(\sigma-\mu_{\mathrm{w}}\right) \tan \left(\varphi^{\prime}\right)
$$

where $s_{\mathrm{r}}$ is the shear strength of the soil $(\mathrm{kPa}), c^{\prime}$ is the effective cohesion $(\mathrm{kPa}), \sigma$ is the normal stress $(\mathrm{kPa}), \mu_{\mathrm{w}}$ is the porewater pressure $(\mathrm{kPa})$, and $\varphi^{\prime}$ is the effective internal angle of friction in degrees (Fredlund and Rahardjo, 1993). With unsaturated conditions, soil shear strength is increased by matric suction (Darby and Thorne, 1996; Crosta and di Prisco, 1999; Darby et al., 2007). In this case the shear strength can be represented by the modified Mohr-Coulomb equation:

$$
s_{\mathrm{r}}=c^{\prime}+\sigma \tan \left(\varphi^{\prime}\right)+\psi \tan \left(\varphi^{\mathrm{b}}\right)
$$

where $\psi$ is the matric suction $(\mathrm{kPa})$ and $\varphi^{\mathrm{b}}$ is an angle that describes the relationship between shear strength and matric suction (degrees). Fredlund and Rahardjo (1993) assume $\varphi^{\mathrm{b}}$ to be between 10 and 20 degrees and that $\varphi^{\mathrm{b}}$ approaches $\varphi^{\prime}$ at saturation. Soil weight is the dominating driving force defined by

$$
s_{\mathrm{d}}=W \sin (\beta)
$$

where $s_{\mathrm{d}}$ is the driving stress $(\mathrm{kPa}), W$ is the weight of the wet soil block per unit area of failure plane $\left(\mathrm{kN} \mathrm{m}^{-2}\right)$, and $\beta$ is the angle of the failure plane in degrees (Simon et al., 2000). Various combinations of failure plane angle and shear emergence elevation (on the bank face) must be considered in order to determine the failure plane with the lowest FoS value, which is the plane on which failure is assumed to occur when FoS approaches unity. Recent versions of BSTEM include a subroutine that uses an iterative procedure to automatically determine this information. In summary, the following soil properties influence bank stability and must be estimated or measured: effective internal angle of friction $\left(\varphi^{\prime}\right)$, effective cohesion $\left(c^{\prime}\right)$, unit weight $(W)$, pore-water pressure $\left(\mu_{\mathrm{w}}\right)$ or matric suction $(\psi)$, and the angle $\varphi^{\mathrm{b}}$.

The toe erosion component of BSTEM estimates bank undercutting as a result of fluvial erosion (Simon et al., 2000). The model predicts erosion based on an excess shear stress equation originally proposed by Partheniades (1965). Erosion rate, $\varepsilon\left(\mathrm{m} \mathrm{s}^{-1}\right)$, is calculated as

$$
\varepsilon=\kappa\left(\tau_{\mathrm{o}}-\tau_{\mathrm{c}}\right)^{a}
$$

where $\kappa$ is the erodibility coefficient $\left(\mathrm{m}^{3} \mathrm{~N}^{-1} \mathrm{~s}^{-1}\right), \tau_{\mathrm{o}}$ is the average shear stress $(\mathrm{kPa}), \tau_{\mathrm{c}}$ is the soil's critical shear stress $(\mathrm{kPa})$, and $a$ is an exponent usually assumed to be unity. The $\kappa$ and $\tau_{\mathrm{c}}$ parameters are functions of numerous soil properties. For non-cohesive soils, $\tau_{c}$ is typically estimated based on the median particle diameter of the soil (Garcia, 2008). Rinaldi et al. (2008) noted the difficulty in estimating $\kappa$ and that no direct methods exist for estimating this parameter. The two parameters are difficult to approximate for cohesive soils but can be estimated using various methods. One of these methods was developed by Hanson (1990) using an in situ jet-test device.

The average shear stress $(\mathrm{kPa})$ in BSTEM is calculated using the following equation assuming steady, uniform streamflow (Simon et al., 2000):

$$
\tau_{\mathrm{o}}=\gamma_{\mathrm{w}} R S
$$

where $\gamma_{\mathrm{w}}$ is the unit weight of water $\left(9.81 \mathrm{kN} \mathrm{m}^{-3}\right), R$ is the hydraulic radius $(\mathrm{m})$, and $S$ is the channel slope $\left(\mathrm{m} \mathrm{m}^{-1}\right)$. BSTEM divides the bank profile into 23 separate nodes. For each of these nodes, BSTEM calculates $\tau_{\mathrm{o}}$ depending on the segment of flow affecting each node. This method creates a distribution of boundary shear stresses and not just one average shear stress applied over the entire bank. This is still a simplification of the actual shear stress distribution which can be affected by secondary flow and three-dimensional effects in the near-bank zone (Pizzuto, 2008). Papanicolaou et al. (2007) suggested that due to secondary currents the bottom half of the streambank may experience stress distributions two to three times higher than the shear stress calculated by first order approximations. In BSTEM, the boundary shear stress is corrected for the effects of curvature using the "no-lag kinematic model" (Crosato, 2007):

$$
\tau_{\mathrm{o}}=\frac{r_{\mathrm{w}} n^{2}(u+U)^{2}}{R^{1 / 3}}
$$

where $n$ is Manning's roughness coefficient, $u$ is the reach-averaged water velocity $\left(\mathrm{m} \mathrm{s}^{-1}\right)$, and $U$ is the increase in the nearbank velocity due to superelevation $\left(\mathrm{m} \mathrm{s}^{-1}\right)$.

BSTEM is composed of multiple tabs for inputting geometric, soil, and hydraulic properties and outputting model results. The "Input Geometry" tab contains fields to input the bank profile, soil layer thickness, and channel and flow parameters. Up to five distinct soil layers can be defined with up to 23 points to define the bank profile. Soil properties for each soil layer indicated on the "Input Geometry" tab are input in the "Bank Material" tab. Users can select default soil parameter values for a given soil type or input user defined values. This tab also contains calculations for estimating $\tau_{c}$ based on particle diameter and estimating $\kappa$ based on $\tau_{c}$ (Hanson and Simon, 2001). The "Bank Model Output" tab requires the user to input a near bank water table depth or pore-water pressures at several depths. The bank stability model is initiated from this tab and displays the results including the FoS, bank geometry, and failure plane emergence elevation and angle. If an FoS value of less than 1.0 is calculated, the program will display the new failed geometry. This new geometry can be exported back into the "Input Geometry" tab for further analysis. The "Toe Erosion Output" tab allows users to initiate the toe erosion module for a specified flow duration. Results displayed include calculated shear stress, new bank profile, and the amount of erosion. Again, this new bank profile can be exported back to the "Input Geometry" tab for further analysis.

BSTEM has been frequently used to simulate bank stability and lateral retreat for estimating stream sediment loading (Simon et al., 2009), stream rehabilitation projects (Lindow et al., 2009), and research on streambank erosion and failure mechanisms (Wilson et al., 2007; Cancienne et al., 2008). However, few, if any, independent evaluations of BSTEM with long-term streambank erosion and failure data have been conducted. Such a data set will also help answer questions relative to which streambank parameters are most critical for deriving appropriate estimates of lateral streambank retreat on composite streambanks. The importance of near-bank groundwater on streambank erosion and failure has been emphasized (Simon et al., 2000; Rinaldi et al., 2008; Fox and Wilson, 2010), but little practical guidance has been provided on how to consider this mechanism of instability.

Therefore, the objectives of this research were to (1) monitor long-term composite streambank retreat during a hydraulically active period on a rapidly migrating stream, (2) evaluate BSTEM's ability to predict the measured streambank retreat, and (3) assess the importance of accurate geotechnical, fluvial erosion, and near-bank pore-water pressure properties. Note that calibration and validation of the model was not the goal of this research (i.e., there are several parameters that can be adjusted in the model to match the observed data), but rather 
a

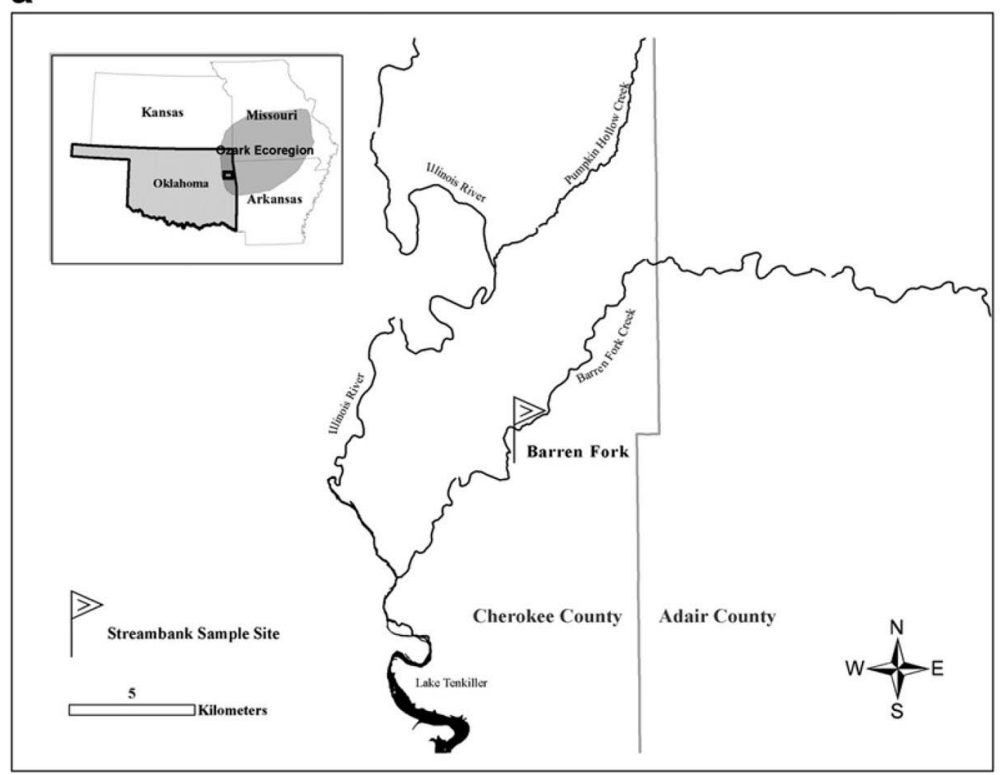

b

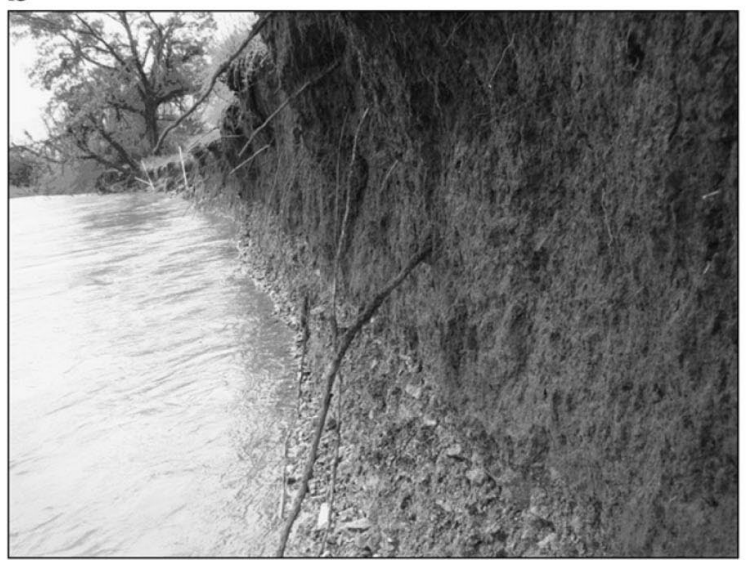

C

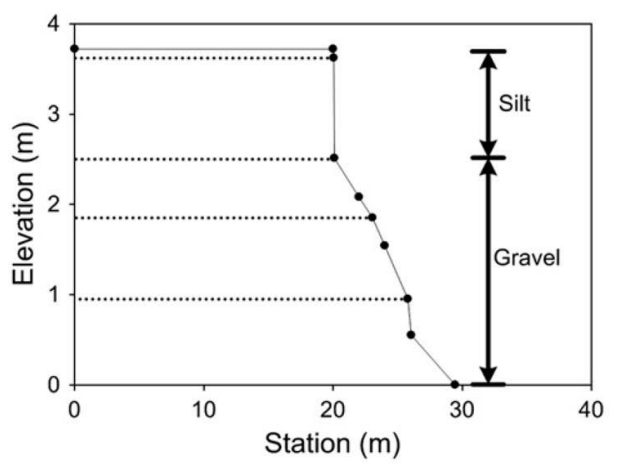

Figure 1. The Barren Fork Creek study site and streambank. (a) Map showing the location of the study site. (b) Streambank profile shortly after a geotechnical failure showing upper consolidated silt loam and underlying unconsolidated alluvial gravel deposits. (c) Initial bank profile of the streambank along with streambank nodes and layers used in BSTEM simulations.

to use the model with appropriate data collection methods that would be followed by practitioners.

\section{Materials and methods}

\subsection{Field site}

The Barren Fork Creek is a fourth order stream located in eastern Oklahoma (OK), USA. The creek originates in northwestern Arkansas, flows through the Boston Mountains and Ozark Highlands ecoregions, and reaches its confluence with the Illinois River at Lake Tenkiller near Tahlequah, OK (Dauwalter and Fisher, 2008). The creek experiences a median discharge of $3.6 \mathrm{~m}^{3} \mathrm{~s}^{-1}$. The site in question is located downstream $(2.2 \mathrm{~km})$ of the Eldon Bridge U.S. Geological Survey $\left(35.90^{\circ} \mathrm{N}, 94.85^{\circ} \mathrm{W}\right)$ gage station (Figure 1a). The field bordering the creek is harvested during the summer for forage production.

The site includes an alluvial floodplain with soil profiles consisting of Razort and Elsah silt loam topsoil overlying unconsolidated alluvial gravel deposits as shown in Figure $1 \mathrm{~b}$. Thorne and Tovey (1981) refer to these types of streambanks as composite banks. The streambank at the field site was $3.72 \mathrm{~m}$ tall with near vertical slopes for the cohesive soil material (Figure 1c). The height of the gravel layer on the bank face varied along the 100-m reach (Fox et al., 2011; Heeren et al., 2011); therefore, average heights of the both the loam topsoil and gravel were used in the BSTEM simulations. In general, the loam topsoil had depths below ground surface between 0.5 and $1.5 \mathrm{~m}$ at the site. Stream slope at the field location was 0.002 (Dauwalter and Fisher, 2008) and the gravel subsoils had a median particle diameter $\left(d_{50}\right)$ of $13 \mathrm{~mm}$ (Fuchs et al., 2009; Heeren et al., 2010; Fox et al., 2011).

Four detailed site surveys were conducted using standard survey equipment between April 18th and October 15th, 2009, after noticeable bank retreat occurred (Figure 2). Other site visits occurred during this time but no surveys were conducted since observable bank retreat had not occurred. Bank retreat was measured relative to a series of shallow groundwater monitoring wells installed at the site for a different project (Fuchs et al., 2009; Heeren et al., 2010). Well locations and the position of the bank were surveyed using a TOPCON HiperLite Plus global positioning system configured with a base station and rover unit (4 $\mathrm{cm}$ accuracy).

\subsection{Modified BSTEM}

A 30-minute resolution flow hydrograph was obtained from the USGS Eldon Bridge gage station approximately $2.2 \mathrm{~km}$ up 


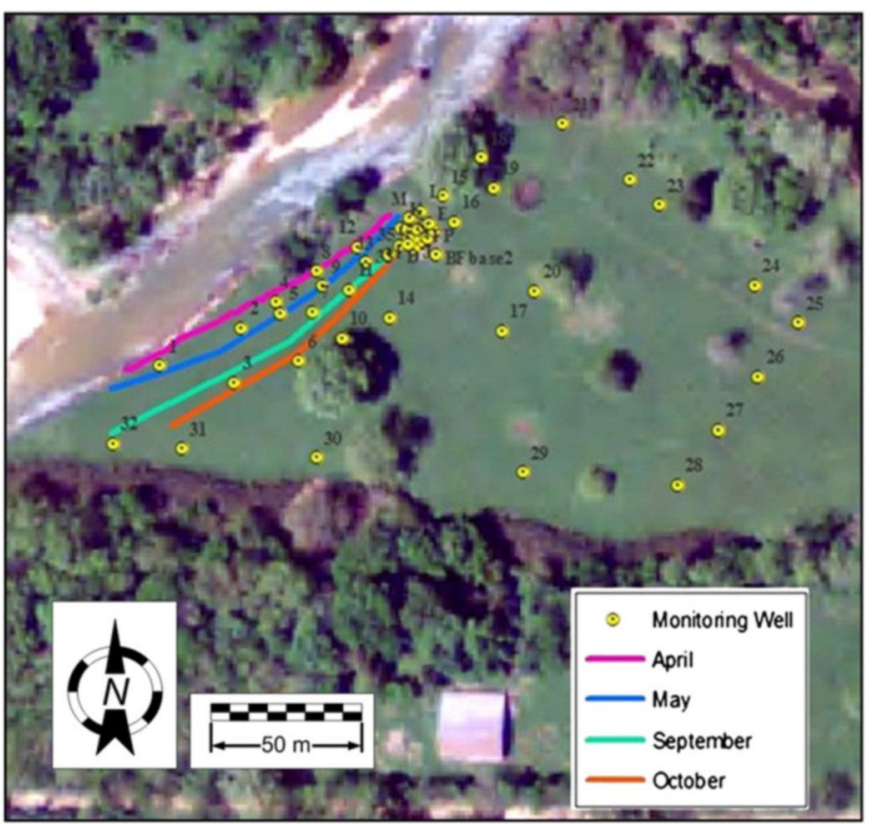

Figure 2. Aerial photograph of the Barren Fork site showing bank retreat (colored lines) at different times during the summer of 2009. Monitoring wells are indicated by circles used for monitoring flow and water quality for a different project (Heeren et al., 2011) and provided a reference for migration rates.

stream of the Barren Fork site from April 18, 2009 to October 15, 2009 (8,468 stream stage observations). The recorded USGS stage was modified for the difference in actual site stage and recorded gage stage. The relative gage reading was converted to an actual stream depth near the gage station, and it was assumed that stream stage would be similar at the site. A water level logger was installed in the stream during a subset of the modeled time period in April 2009 at the field site, and this logger demonstrated that this conversion was appropriate. In order to facilitate the input of the entire 8468 hydrograph points, BSTEM automation was necessary. A new subroutine written in Visual Basic was added to the BSTEM code which automatically input the next point once the previous point's analysis was complete. Using the modified BSTEM required the following steps:

1. input the entire hydrograph on a new "Input Hydrograph" tab along with the time resolution,

2. input bank profile and flow parameters in the "Input Geometry" tab (the original bank profile was derived from April 15, 2009 pictures of the streambank),

3. input the soil geotechnical and fluvial parameters in the "Bank Material" tab, and

4. run the new subroutine which follows the process indicated in Figure 3.

A new tab for all outputs was created called "Output Data". In this sheet, the program simply lists the date and time of the hydrograph point, the flow elevation, geotechnical results if the bank was geotechnically unstable, fluvial erosion results if the bank was geotechnically stable, and the near bank water table height for each time step. The eight simulations performed with the modified BSTEM for the Barren Fork Creek streambank are summarized in Table 1.

\subsection{Soil parameter estimation}

To determine the importance of measured versus assumed soil parameter values, BSTEM simulations were conducted with default values for the given soil type using five streambank layers; additional simulations were conducted with measured values from either in situ or laboratory measurements. BSTEM contains several soil types with default soil parameter values. The available cohesive soil types include stiff clay, soft clay, or silt which can each be further classified as resistant, moderate, or erodible. Noncohesive soils include boulders, cobbles, gravel, coarse and fine angular sand, and coarse and fine rounded sand. Moderate silt for the upper soil profile layers and gravel for the lower layers were selected for the BSTEM default simulations.

In order to measure geotechnical parameters for the cohesive soil, direct shear tests were conducted on extracted soil cores from the streambank following ASTM Standards (D3080-98). Three tests were conducted on each of three silt loam soil samples collected at the site. The tests were run near saturation in order to remove apparent cohesion. A failure envelope was derived for each sample; $c^{\prime}$ was derived from the

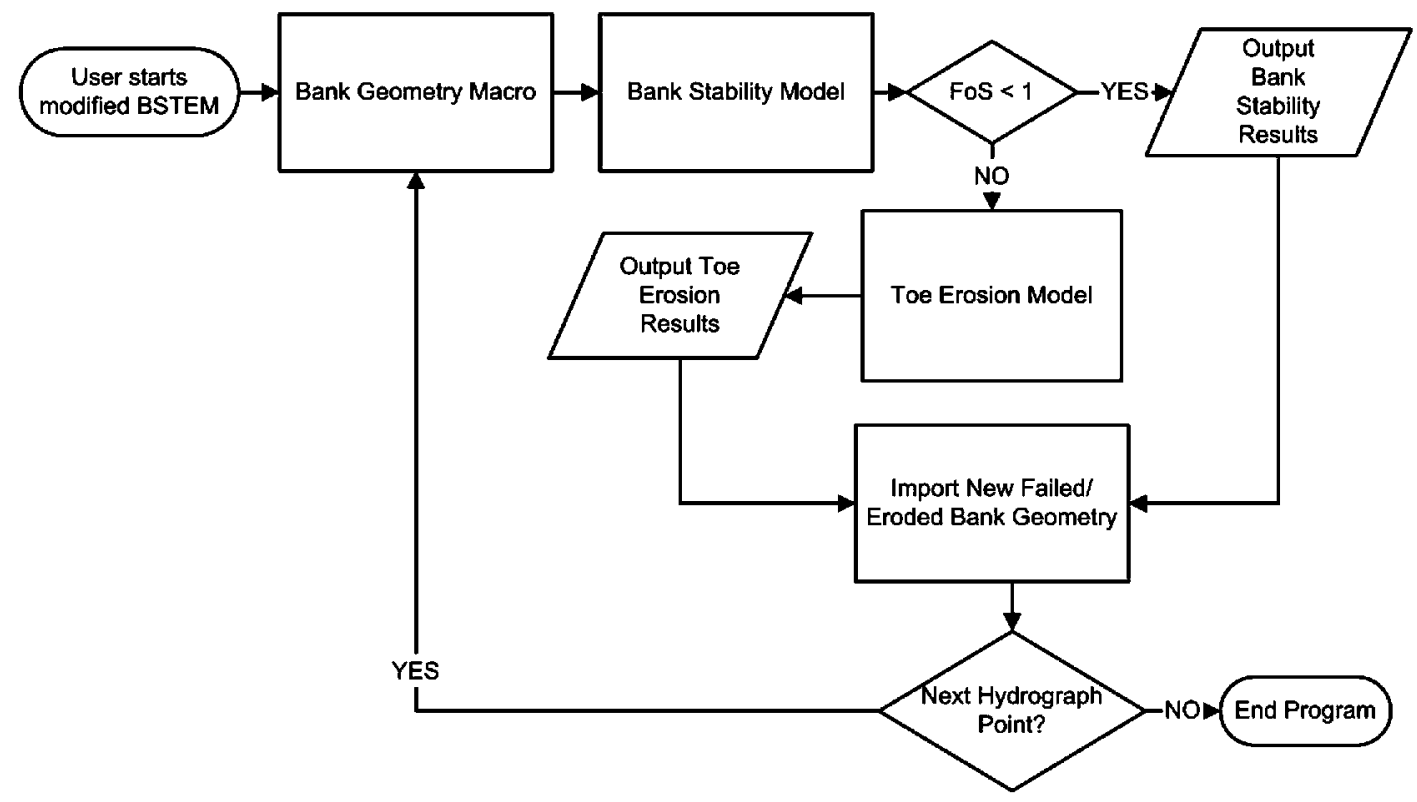

Figure 3. Process followed by the modified BSTEM in order to iteratively simulate a summer long flow hydrograph. This process was programmed into BSTEM v5.2 specifically for this research project. 
Table 1. Summary of BSTEM simulations of the Barren Fork Creek streambank migration from April to October 2009.

\begin{tabular}{clll}
\hline Simulation \# & $\begin{array}{l}\text { Geotech } \\
\text { Values }^{\mathrm{a}}\end{array}$ & $\begin{array}{l}\text { Fluvial } \\
\text { Values }^{\mathrm{a}}\end{array}$ & $\begin{array}{l}\text { Water Table } \\
\text { Response }^{\mathrm{b}}\end{array}$ \\
\hline 1 & Default & Default & Instant \\
2 & Default & Default & Delayed \\
3 & Measured & Default & Instant \\
4 & Measured & Default & Delayed \\
5 & Default & Measured & Instant \\
6 & Default & Measured & Delayed \\
7 & Measured & Measured & Instant \\
8 & Measured & Measured & Delayed \\
\hline
\end{tabular}

a. Measured refers to simulations in which the measured values were used. Default refers to simulations in which the BSTEM default values were used.

b. Instant water table lag means the near bank water table was set to match the flow elevation. Delayed response simulations had water table changes that lagged the stream flow elevation.

$y$-intercept and $\varphi^{\prime}$ was derived from the slope angle. For the non-cohesive soil, $c^{\prime}$ was assumed to be zero and $\varphi^{\prime}$ was measured as the angle of repose of the gravel.

The fluvial parameters ( $\kappa$ and $\tau_{c}$ ) for the cohesive soil were measured in situ using a submerged jet test device designed by Hanson (1990). The device was setup following Hanson and Cook (2004). In order to create a measurable scour hole from which $\tau_{c}$ and $\kappa$ can be calculated, the jet test device directs a jet of water towards the soil. A pump provides water to an adjustable constant head reservoir which powers the jet. Head for the jet was set near a level that the streambank would have experienced during a flood event. A base for the jet test device was driven into the soil at the desired test location. The soil and the steel ring of the base acted as the bottom of a submergence tank. The device was then placed on the base and locked in, sealing the device to the base. The submergence tank was filled with water and testing initiated. Periodically, the jet was blocked by a deflector plate and an installed point gauge was used to measure the depth of the scour hole. The system and installed device are shown in Figure 4.

Six different jet tests were conducted in the cohesive soil at the site. The value of $\tau_{c}$ was estimated based on the scour hole depth when the experiment time was sufficient to reach an equilibrium scour depth (Hanson and Cook, 2004), which occurred for two of the six tests. This assumed the hole ceased eroding once the distance from the jet to the bottom of the scour hole was large enough to allow the shear stress caused by the jet to drop below $\tau_{c}$ of the soil (Hanson and Cook, 2004). The value of $\kappa$ was calculated based on the relationship between scour hole depth and time for all six tests. For further explanation of these calculations refer to Hanson and Cook (2004).

Following BSTEM procedures and without measurement techniques available (Rinaldi et al., 2008), values for $\kappa$ and $\tau_{\mathrm{c}}$ for the non-cohesive soil were estimated from $d_{50}$ of the gravel and the relationship derived by Hanson and Simon (2001):

$$
\kappa=2 \times 10^{-7} \tau_{\mathrm{c}}^{-1 / 2}
$$

This relationship was developed empirically based on cohesive soils, but is used by BSTEM for non-cohesive soils. Extrapolation to the gravel soils at the site may not be appropriate; therefore, because of the uncertainty of $\tau_{c}$ and $\kappa$ for the gravel, five additional simulations were conducted in which $\tau_{c}$ was reduced by a factor of 2,5 and 10 and $\kappa$ was multiplied by 2 and 5 in order to increase the predicted erosion. The percent change in predicted bank retreat from the baseline scenario (simulation 8 in Table 1) was calculated for each changed input value.

Field and numerical modeling research has also demonstrated that the addition of roots to streambanks improves stability under a range of hydrological conditions (Abernathy and Rutherfurd, 2000, Wynn et al., 2004, Wynn and Mostaghimi, 2006 and Pollen, 2007). However, the additional cohesive strength added to the streambank from the perennial grasses on the bank surface was not considered in this research. A small soil layer was included at the top of the BSTEM streambank profile (Figure 1c) and its fluvial erosion properties modified to add additional fluvial erosion resistance to the top streambank material because of the presence of the grasses on the bank surface.

\subsection{Groundwater Table Lag}

In order to determine the importance of the near bank water table elevation, two methods of specifying the groundwater table elevation were tested. In "Instant Response" simulations, the near bank water table was automatically input to match the elevation of the stream stage. In "Delayed Response" simulations, the water table lagged behind the flow elevation for a set amount of time depending on the soil layer. In the unconsolidated gravel layer, the water table lagged flow elevation changes by $1 \mathrm{~h}$. In the consolidated cohesive top soil, the water table lagged flow elevation changes by $24 \mathrm{~h}$. This approach was realized to be an approximation to the actual porewater pressure dynamics in the soil near the streambank face, but was deemed reasonable based on reported soil hydraulic properties measured at the site (Fuchs et al., 2009; Heeren et al., 2010; Miller et al., 2011).

\section{Results and discussion}

\subsection{Bank Retreat}

Measured bank retreat ranged from 7.8 to $20.9 \mathrm{~m}$ along the $100 \mathrm{~m}$ of bank at the Barren Fork Creek site (Figure 2). Most failures were observed to occur by toe erosion undercutting of the unconsolidated gravel leading to geotechnical failure

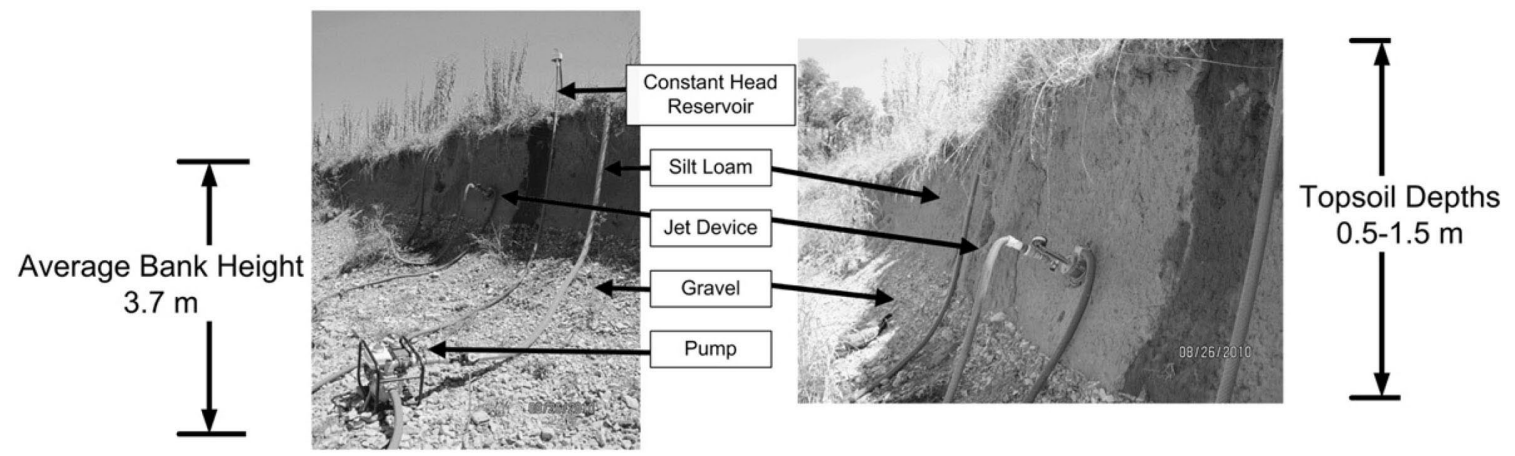

Figure 4. Jet test experiments on the Barren Fork streambank for measuring resistance of the bank material to fluvial erosion. Scales are approximate and indicate range in some cases. 
Table 2. Default and measured geotechnical and fluvial soil parameter values used in the BSTEM simulations.

\begin{tabular}{|c|c|c|c|c|c|}
\hline & & \multicolumn{2}{|c|}{ Cohesive Soil } & \multicolumn{2}{|l|}{ Gravel } \\
\hline & & $\begin{array}{l}\text { BSTEM } \\
\text { Default }\end{array}$ & $\begin{array}{l}\text { Meas. } \\
\text { / Est. }\end{array}$ & $\begin{array}{l}\text { BSTEM } \\
\text { Default }\end{array}$ & $\begin{array}{l}\text { Meas. } \\
\text { /Est. }\end{array}$ \\
\hline \multicolumn{6}{|l|}{ Geotechnical Variables } \\
\hline $\begin{array}{l}\text { Effective Friction } \\
\text { Angle, } \varphi^{\prime}\end{array}$ & degrees & 30.0 & 22.7 & 36.0 & 30.7 \\
\hline Effective Cohesion, $c^{\prime}$ & $\mathrm{kPa}$ & 3.0 & 0.7 & 0.0 & 0.0 \\
\hline $\begin{array}{l}\text { Saturated Unit } \\
\text { Weight, } \gamma_{\mathrm{sat}}\end{array}$ & $\mathrm{kN} \mathrm{m}^{-3}$ & 18.0 & 19.5 & 20.0 & 17.3 \\
\hline $\begin{array}{l}\text { Matric Suction } \\
\text { Angle, } \varphi^{\mathrm{b}}\end{array}$ & degrees & 15 & $15^{\mathrm{a}}$ & 15 & $15^{\mathrm{a}}$ \\
\hline \multicolumn{6}{|c|}{ Fluvial Erosion Variables } \\
\hline $\begin{array}{l}\text { Critical Shear } \\
\text { Stress, } \tau_{\text {. }}\end{array}$ & $\mathrm{Pa}$ & 5.00 & 0.21 & 11.0 & $12.64^{b}$ \\
\hline Erodibility, $\kappa$ & $\mathrm{cm}^{3} \mathrm{~N}^{-1} \mathrm{~s}^{-1}$ & 0.05 & 5.85 & 0.03 & $0.03^{c}$ \\
\hline
\end{tabular}

a. Assumed equal to BSTEM default values.

b. Estimated from the Shields-Yalin diagram based on the measured average particle size.

c. Estimated from the Hanson and Simon (2001) relationship (utilized by BSTEM) between $\tau_{c}-\kappa$ for excess shear stress formulation of erosion rate used in BSTEM.

of the overlying consolidated silt loam topsoil. The most significant lateral retreat occurred in mid- to late-May and September due to a series of storm events, and not necessarily the most extreme event observed during the monitoring period. Such results emphasize the critical link between fluvial undercutting and geotechnical stability in these alluvial streams.

\subsection{Soil parameter estimation}

The BSTEM default parameter values and the measured values are outlined in Table 2. The greatest differences between measured and default parameters were observed in the cohesive soil's fluvial erosion parameters (e.g., $\tau$ and $\kappa$ ). The value of $\tau_{c}$ decreased by an order of magnitude while $\kappa$ increased by two orders of magnitude when measuring these parameters in situ. Parameters derived from the submerged jet tests were consistent among the three measurement locations (i.e., the coefficients of variation for $\tau_{c}$ and $\kappa$ were 1.3 and 0.2 , respectively). The other parameter values were similar between the default and measured values and within the expected range of the specific parameters for this soil type. The erodibility coefficient, $\kappa$, for the noncohesive gravel at the bank toe was estimated to be $0.03 \mathrm{~cm}^{3} \mathrm{~N}^{-1} \mathrm{~s}^{-1}$ from Equation (7).

\subsection{Modeling bank retreat}

BSTEM underestimated the bank retreat at the Barren Fork Creek site (Table 3), but did tend to correctly predict the timing of failures as shown in Figure 5. Note that while it appears that in some cases BSTEM-predicted bank retreats earlier than measured bank retreat, the observed data were not continuous; measurements were performed at various times during the year after high flow events. In some cases, the observed data were not recorded until a few days to weeks after high flow events depending on the availability of personnel. Several time steps $(15,30$, and 60 minutes) were investigated, but had insignificant effects on simulated bank retreat results. Simulations 1 and 5 predicted no bank retreat for the entire hydrograph. These simulations included both the BSTEM default geotechnical parameter values and an instant response water table. For a delayed water table response, using measured geotechnical properties and default fluvial erosion parameters predicted greater lateral bank retreat $(2.6 \mathrm{~m}$ with four bank failures) than when using default geotechnical and measured fluvial parameters (1.3 $\mathrm{m}$ with two bank failures).
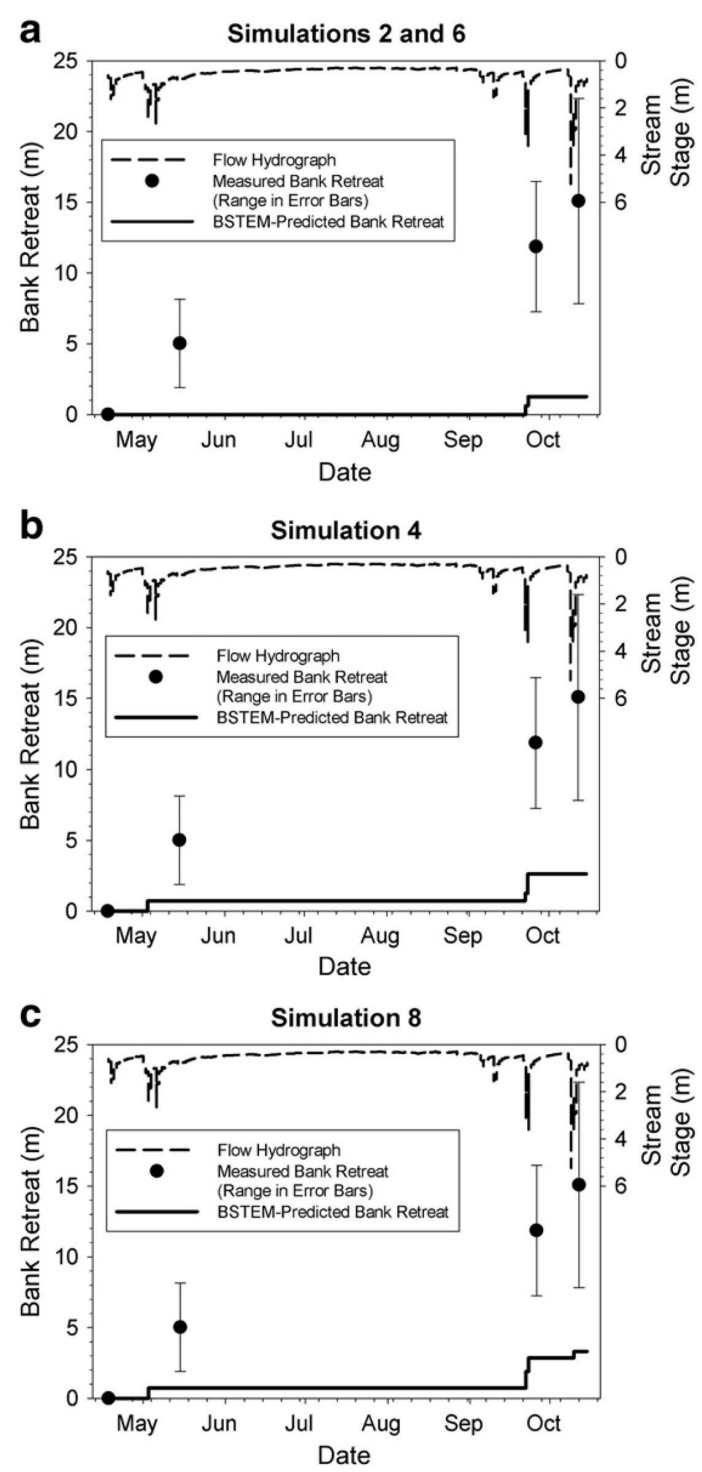

Figure 5. Comparison of measured bank retreat (symbols with error bars to demonstrate the range over $100 \mathrm{~m}$ of bank) versus BSTEM-predicted bank retreat for simulations 2, 4, 6, and 8 (see Table 3 for a description of the simulations). Sampling times of measured bank retreat are shown when surveying indicated additional lateral migration.

Table 3. Predicted bank retreat by the BSTEM simulations.

\begin{tabular}{|c|c|c|c|c|c|}
\hline $\begin{array}{l}\text { Simulation } \\
\#\end{array}$ & $\begin{array}{l}\text { Geotech } \\
\text { Values } \\
\text { (Default/ } \\
\text { Measured) }\end{array}$ & $\begin{array}{l}\text { Fluvial } \\
\text { Values } \\
\text { (Default/ } \\
\text { Measured) }\end{array}$ & $\begin{array}{l}\text { Water Tabl } \\
\text { Response } \\
\text { (Instant/ } \\
\text { Delayed) }\end{array}$ & $\begin{array}{l}\text { Bank } \\
\text { Retreat } \\
(\mathrm{m})\end{array}$ & $\begin{array}{l}\text { Number } \\
\text { of } \\
\text { Failures }\end{array}$ \\
\hline 1 & Default & Default & Instant & 0.0 & 0 \\
\hline 2 & Default & Default & Delayed & 1.3 & 2 \\
\hline 3 & Measured & Default & Instant & 1.4 & 3 \\
\hline 4 & Measured & Default & Delayed & 2.6 & 4 \\
\hline 5 & Default & Measured & Instant & 0.0 & 0 \\
\hline 6 & Default & Measured & Delayed & 1.3 & 2 \\
\hline 7 & Measured & Measured & Instant & 2.2 & 4 \\
\hline 8 & Measured & Measured & Delayed & 3.3 & 6 \\
\hline
\end{tabular}

Several reasons may account for the consistent under estimation of lateral bank retreat predicted by BSTEM for all simulations. First, measuring fluvial erosion and geotechnical parameters are difficult and numerous soil properties influence these parameters; however, the measured parameters decreased the error over the default BSTEM values. Two of the most uncertain parameters were $\tau_{c}$ and $\kappa$ for the non-cohesive gravel due to the lack of direct measurement techniques 

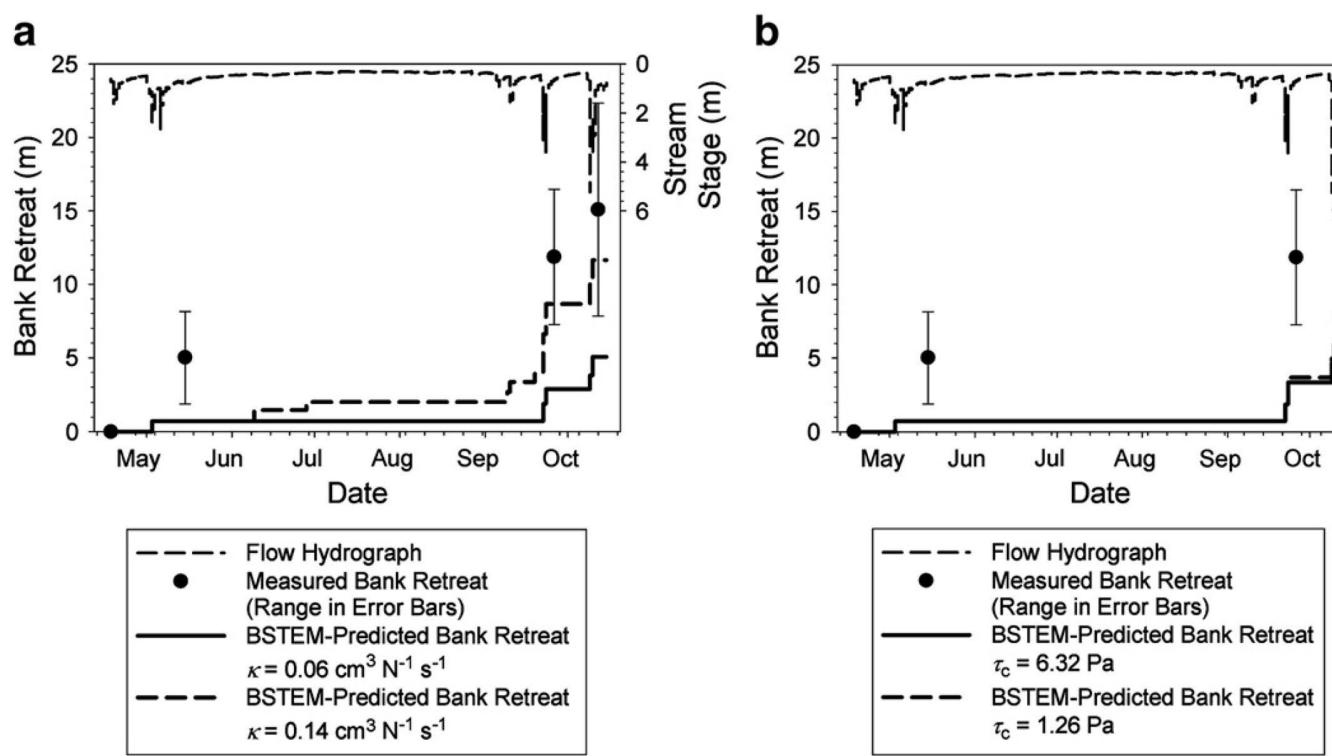

Figure 6. Comparison of measured bank retreat (symbols with error bars to demonstrate the range over $100 \mathrm{~m}$ of bank) versus BSTEM-predicted bank retreat for simulations. (a) Erodibility coefficient $\left(\kappa=0.03 \mathrm{~cm}^{3} \mathrm{~N}^{-1} \mathrm{~s}^{-1}\right)$ estimated from the empirical $\tau_{c}-\kappa$ relationship multiplied by $2\left(\kappa=0.06 \mathrm{~cm}^{3} \mathrm{~N}^{-1} \mathrm{~s}^{-1}\right)$ and $5\left(\kappa=0.14 \mathrm{~cm}^{3} \mathrm{~N}^{-1} \mathrm{~s}^{-1}\right)$. (b) Critical shear stress $\left(\tau_{\mathrm{c}}\right)$ estimated from Shields-Yalin $\left(\tau_{\mathrm{c}}=12.64 \mathrm{~Pa}\right)$ divided by 2 $\left(\tau_{\mathrm{c}}=6.32 \mathrm{~Pa}\right)$ and $10\left(\tau_{\mathrm{c}}=1.26 \mathrm{~Pa}\right)$.

for these parameters (Rinaldi et al., 2008). Increasing $\kappa$ and decreasing $\tau_{\mathrm{c}}$ of the gravel did provide greater bank retreat due to greater fluvial undercutting of the toe (Figure 6, Table 4). It should also be noted that percent change in bank retreat due to large changes in $\tau_{\mathrm{c}}$ and $\kappa$ of the gravel layer was on the order of $100 \%$ (Table 4). BSTEM simulation results are not highly sensitive to any one input parameter. If practitioners are limited to the best available data, this limitation does not preclude them from obtaining useful results.

It may be advantageous to incorporate more fundamental transport equations of hydraulic scour for non-cohesive materials into BSTEM rather than using an excess shear stress formulation for all possible streambank layers; however, the issue of deriving reasonable estimates of parameters for any mathematical formulation of the toe erosion process remains.

An interesting by-product of analyzing the impact of $\tau_{\mathrm{C}}$ and $\kappa$ was that BSTEM predicted slightly variable bank retreat results for the same input parameters over the longterm simulation. This variability was due to the automated routine used by the program to locate the failure plane with the lowest FoS value. The automated routine was coded using a random step function that allowed the routine to converge on a slightly different solution (failure plane angle and shear emergence elevation) when repeated for the same problem. These small differences were always present but resulted in larger differences in bank retreat for simulations with a larger number of bank failures. Reducing the time step to 15-minute increments did not alleviate this variability. Future versions of the model are being developed with improved failure plane search routines.

Table 4. Percent change in predicted bank retreat by BSTEM relative to the base scenario (simulation 8 in Table 1), with changes in erodibility $(\kappa)$ and critical shear stress $\left(\tau_{c}\right)$ of the unconsolidated, gravel layer (base values were $\kappa=0.03 \mathrm{~cm}^{3} \mathrm{~N}^{-1} \mathrm{~s}^{-1}$ and $\tau_{\mathrm{c}}=12.64 \mathrm{~Pa}$ ).

\begin{tabular}{lll}
\hline Parameter & Value & $\begin{array}{l}\text { Percent Change in } \\
\text { Predicted Bank Retreat }(\%)\end{array}$ \\
\hline$\kappa\left(\mathrm{cm}^{3} \mathrm{~N}^{-1} \mathrm{~s}^{-1}\right)$ & 0.06 & 53 \\
$\kappa\left(\mathrm{cm}^{3} \mathrm{~N}^{-1} \mathrm{~s}^{-1}\right)$ & 0.14 & 252 \\
$\tau_{\mathrm{c}}(\mathrm{Pa})$ & 6.32 & 80 \\
$\tau_{\mathrm{c}}(\mathrm{Pa})$ & 2.53 & 91 \\
$\tau_{\mathrm{c}}(\mathrm{Pa})$ & 1.26 & 93 \\
\hline
\end{tabular}

Second, BSTEM only accounts for fluvial erosion with a simple channel geometry assuming steady, uniform streamflow and bank stability for cohesive sediment based on the Mohr-Coulomb theory; other mechanisms may be present, such as soil piping (Fox and Wilson, 2010) and secondary currents. Imposed shear stresses are much greater in natural channels around or near bends (Papanicolaou et al., 2007). Previous research has indicated that complex flow patterns around meander bends drastically modify the expected shear stress distribution from the assumption of steady, uniform flow (Papanicolaou et al., 2007; Pizzuto, 2008). Using Crosato's (2007) "no-lag kinematic model" predicted an increased boundary shear stress (up to 2.5 times at peak flow) but resulted in no additional bank retreat than the same simulation with the excess shear stress equation. More sophisticated formulations can be used to increase the boundary shear stress, as it was hypothesized that applied shear stresses are still under predicted, but this is again dependent on data to represent this process. Otherwise, multidimensional computational fluid dynamics simulations are required.

Finally, increased water content in the streambank resulted in loss of shear strength, increased soil weight, and decreased stability. The strategy used in this research may have incorrectly assumed the water table lag, and therefore underestimated the instability. The water table response in the simulated streambank strongly affected bank stability. Some simulations resulted in no bank retreat when assuming an instant water table response, but over $1 \mathrm{~m}$ of retreat with a delayed response. Therefore, this research supports previous findings by Simon et al. (2000), Rinaldi et al. (2008), and Fox and Wilson (2010) that the removal of negative soil pore-water pressures reducing the shear strength of the soil is important for destabilizing streambanks. In fact, bank sediment (topsoil) was deposited on the toe during site visits suggesting geotechnical failure at times when fluvial stresses could not mobilize failed material. Such instability mechanisms have been discussed in detail by Rinaldi and Casagli (1999), Simon et al. (1999), Darby et al. (2007), and Rinaldi et al. (2008). More work needs to be done to refine BSTEM in terms of better predicting near bank water table elevation and incorporating other failure mecha- 
nisms by groundwater flow (Fox and Wilson, 2010). Future versions of BSTEM are being developed with a simplified groundwater model.

It should be noted that BSTEM assumed all failed material from mass wasting events to be immediately removed, not accumulating on the toe. The failure to address this issue should overestimate the bank retreat, but as shown above the model underestimated bank retreat in all simulations.

\section{Conclusions}

For a multilayered streambank consisting of cohesive topsoil underlain by unconsolidated gravel in eastern Oklahoma, the most significant retreat occurred during a series of high flow events as opposed to isolated large flow events, suggesting the importance of linked fluvial erosion and geotechnical resistance in the lateral retreat process. BSTEM under predicted observed lateral bank retreat, and the under estimation was greatest with default fluvial and geotechnical soil parameters and when not including a delayed water table response, which allows the pore-water pressures to decrease rapidly in the near-bank groundwater and increase stability. The water table response in the streambank strongly affected bank stability and additional work needs to be done to refine BSTEM in terms of better predicting near bank pore-water pressure dynamics. Since the timing of bank collapses was more appropriately predicted, the under prediction of streambank retreat was most likely due to over predicting the critical shear stress and/or under predicting the erodibility of the non-cohesive gravel. It is hypothesized that the under prediction of fluvial undercutting in BSTEM led to fewer streambank failures within single storm events than what actually occurred in the field. BSTEM uses an excess shear stress formulation for both non-cohesive and cohesive fluvial erosion and no direct methods exist for measuring the erodibility of non-cohesive gravels. Improving methods to estimate fluvial erosion of non-cohesive sediment, understanding shear stress distributions due to complex flow patterns in meander bends, and improving our ability to predict near streambank pore-water pressure will be critical for future updates to BSTEM and other streambank stability models.

Acknowledgments - This paper is based upon work supported by the National Science Foundation under Grant No. 0943491. Any opinions, findings, and conclusions or recommendations expressed in this material are those of the authors and do not necessarily reflect the views of the National Science Foundation. The authors acknowledge Abdul-Sahib Al-Madhhachi, Ph.D. student, Civil and Environmental Engineering Department, Oklahoma State University, for providing assistance with the jet test device.

\section{Appendix A. Supplementary data}

The ZIP file attached to the html "index" page for this article contains the Google map of the most important areas described herein.

\section{References}

Abernathy, B., Rutherfurd, I. D., 2000. The effect of riparian tree roots on the mass-stability of riverbanks. Earth Surface Processes and Landforms 25, 921-937.

Bernhardt, E. S., Palmer, M. A., Allan, J. D., Alexander, G., Barnas, K., Brooks, S., Carr, J., Clayton, S., Dahm, C., Follstad-Shah, J., Galat, D., Gloss, S., Goodwin, P., Hart, D., Hassett, B., Jenkinson, R., Katz, S., Kondolf, G. M., Lake, P. S., Lave, R., Meyer, J. L., O’Donnell, T. K., Pagano, L., Powell, B., Sudduth, E., 2005. Synthesizing U. S. river restoration efforts. Science 308, 636-637.
Cancienne, R., Fox, G. A., Simon, A., 2008. Influence of seepage undercutting on the root reinforcement of streambanks. Earth Surface Processes and Landforms 33, 1769-1786.

Crosato, A., 2007. Physical explanations of variations in river meander migration rates from model comparison. Earth Surface Processes and Landforms 34, 2078-2086.

Crosta, G., di Prisco, C., 1999. On slope instability induced by seepage erosion. Canadian Geotechnical Journal 36, 1056-1073.

Darby, S. E., Thorne, C. R., 1996. Numerical simulation of widening and bed deformation of straight sand-bed rivers. I. Model development. Journal of Hydraulic Engineering 122, 184-193.

Darby, S. E., Rinaldi, M., Dapporto, S., 2007. Coupled simulations of fluvial erosion and mass wasting for cohesive river banks. Journal of Geophysical Research 112, F03022. doi:10. 1029/2006JF000722.

Dauwalter, D. C., Fisher, W. L., 2008. Spatial and temporal patterns in stream habitat and smallmouth bass populations in eastern Oklahoma. Transactions of the American Fisheries Society 137, 1072-1088.

Evans, D. J., Gibson, C. E., Rossell, R. S., 2006. Sediment loads and sources in heavily-modified Irish catchments: A move towards informed management strategies. Geomorphology 79, 93-113.

Fox, G. A., Wilson, G. V., 2010. The role of subsurface flow in hillslope and streambank erosion: A review. Soil Science Society of America Journal 74, 717-733.

Fox, G. A., Heeren, D. M., Miller, R. B., Mittelstet, A. R., Storm, D. E., 2011. Flow and transport experiments for a streambank seep originating from a preferential flow pathway. Journal of Hydrology 403 (3-4), 360-366.

Fredlund, D. G., Rahardjo, H., 1993. Soil Mechanics of Unsaturated Soils. John Wiley and Sons, Inc., New York, NY.

Fuchs, J. W., Fox, G. A., Storm, D. E., Penn, C., Brown, G. O., 2009. Subsurface transport of phosphorus in riparian floodplains: Influence of preferential flow paths. Journal of Environmental Quality 38 (2), 473-484.

Garcia, M., 2008. Sediment transport and morphodynamics. In: Garcia, M. (ed.), Sedimentation Engineering: Processes, Measurements, Modeling and Practice. ASCE Manuals and Reports on Engineering Practice No. 110. American Society of Civil Engineers, Reston, VA, pp. 21-164.

Hanson, G. J., 1990. Surface erodibility of earthen channels at high stresses: Developing an in situ testing device. Transactions of the American Society of Agricultural Engineers 33, 132-137.

Hanson, G. J., Cook, K. R., 2004. Apparatus, test procedures, and analytical methods to measure soil erodibility in situ. Applied Engineering in Agriculture 20, 455-462.

Hanson, G. J., Simon, A., 2001. Erodiblity of cohesive sediment in the loess area of the Midwestern USA. Hydrological Processes 15, 23-28.

Heeren, D. M., Miller, R. B., Fox, G. A., Storm, D. E., Penn, C., Halihan, T., 2010. Preferential flow path effects on subsurface contaminant transport in alluvial floodplains. Transactions of the American Society of Agricultural and Biological Engineers 53, 127-136.

Heeren, D. M., Fox, G. A., Miller, R. B., Storm, D. E., Fox, A. K., Penn, C. J., Halihan, T., Mittelstet, A. R., 2011. Stage-dependent transient storage of phosphorus in alluvial floodplains. Hydrological Processes 25, 3230-3243. doi:10. 1002/ hyp. 8054.

Lavendel, B., 2002. The business of ecological restoration. Ecological Restoration 20, 173-178.

Lindow, N., Fox, G. A., Evans, R. O., 2009. Seepage erosion in fluviomarine stream bank material. Earth Surface Processes and Landforms 34, 1693-1701.

Miller, R. B., Heeren, D. M., Fox, G. A., Storm, D. E., Halihan, T., 2011. Design and application of a direct-push in-situ gravel permeameter. Ground Water 49, 920-925.

Papanicolaou, A. N., Elhakeem, M., Hilldale, R., 2007. Secondary current effects on cohesive river bank erosion. Water Resources Research 43, W12418. doi:10. 1029/ 2006WR005763.

Partheniades, E., 1965. Erosion and deposition of cohesive soils. Journal of the Hydraulics Division of the American Society of Civil Engineers 91 (HY1), 105-139.

Pizzuto, J. E., 2008. Streambank erosion and river width adjustment. In: Garcia, M. (ed.), Sedimentation Engineering: Processes, Measure- 
ments, Modeling and Practice. ASCE Manuals and Reports on Engineering Practice No. 110. American Society of Civil Engineers, Reston, VA, pp. 387-438.

Pollen, N., 2007. Temporal and spatial variability in root reinforcement of streambanks: Accounting for soil shear strength and moisture. Catena 69, 197-205.

Rinaldi, M., Casagli, N., 1999. Stability of streambanks formed in partially saturated soils and effects of negative pore water pressures: The Siene River (Italy). Geomorphology 26, 253-277.

Rinaldi, M., Mengoni, B., Luppi, L., Darby, S. E., Mosselman, E., 2008. Numerical simulation of hydrodynamics and bank erosion in a river bend. Water Resources Research 44, W09428. doi:10. 1029/2008WR007008.

Sekely, A. C., Mulla, D. J., Bauer, D. W., 2002. Streambank slumping and its contribution to the phosphorus and suspended sediment loads of the Blue Earth River, Minnesota. Journal of Soil and Water Conservation 57, 243-250.

Simon, A., Collison, A. J. C., 2002. Quantifying the mechanical and hydrologic effects of riparian vegetation on streambank stability. Earth Surface Processes and Landforms 27, 527-546.

Simon, A., Darby, S. E., 1999. The nature and significance of incised river channels. In: Darby, S. E., Simon, A. (eds.), Incised river channels. John Wiley and Sons, Chichester, UK, pp. 3-18.

Simon, A., Curini, A., Darby, S. E., Langendoen, E. J., 1999. Streambank mechanics and the role of bank and near-bank processes in incised channels. In: Darby, S. E., Simon, A. (eds.), Incised River Channels. John Wiley and Sons, Chichester, UK, pp. 193-217.
Simon, A., Curini, A., Darby, S. E., Langendoen, E. J., 2000. Bank and near-bank processes in an incised channel. Geomorphology 35, 183-217.

Simon, A., Pollen-Bankhead, N., Mahacek, V., Langendoen, E., 2009. Quantifying reductions of mass-failure frequency and sediment loadings from streambanks using toe protection and other means: Lake Tahoe, United States. Journal of the American Water Resources Association 45, 170-186.

Thorne, C. R., Tovey, N. K., 1981. Stability of composite river banks. Earth Surface Processes and Landforms 6, 469-484.

Wilson, G. V., Periketi, R., Fox, G. A., Dabney, S., Shields, F. D., Cullum, R. F., 2007. Soil properties controlling seepage erosion contributions to streambank failure. Earth Surface Processes and Landforms 32, 447-459.

Wilson, C. G., Kuhnle, R. A., Bosch, D. D., Steiner, J. L., Starks, P. J., Tomer, M. D., Wilson, G. V., 2008. Quantifying relative contributions fromsediment sources in Conservation Effects Assessment Project watersheds. Journal of Soil and Water Conservation 63, 523-531.

Wynn, T. M., Mostaghimi, S., 2006. Effects of riparian vegetation on stream bank subaerial processes in southwestern Virginia, USA. Earth Surface Processes and Landforms 31, 399-413.

Wynn, T. M., Mostaghimi, S., Burger, J. A., Harpold, A. A., Henderson, M. B., Henry, L. A., 2004. Variation in root density along stream banks. Journal of Environmental Quality 33, 2030-2039. 